\title{
ARTYKUŁY
}

Agata Łysakowska

(Uniwersytet im. A. Mickiewicza w Poznaniu, Wydział Historyczny)

mgr,aklysakowska@gmail.com

\section{Rozwój dziewiętnastowiecznego Szczecina w Geschichte der Stadt Stettin Martina Wehrmanna}

Procesy związane z urbanizacją oraz kształtowaniem nowoczesnych organizmów miejskich były istotnym elementem zachodzącej w XIX w. modernizacji. Miasta stały się wizytówkami tego okresu, a przemiany w nich zachodzące - inspiracją dla wielu przedstawicieli nauki i sztuki. Podczas gdy w Walter Benajmin określił Paryż stolicą XIX w., Władysław Reymont utrwalił w polskiej świadomości Łódź jako „ziemię obiecaną”. Jürgen Osterhammel w swojej pracy Historia XIX wieku. Przeobrażenie świata pisze: „Rozwój miast był w XIX w. bardziej niż kiedykolwiek przedtem wspierany przez siły rynkowe i prywatną inicjatywę. Kariera niektórych spośród największych i najbardziej dynamicznych miast świata była rezultatem prywatnej »obywatelskiej « inicjatywy. Były one w mniejszym stopniu siedzibami władzy i prestiżowej kultury wysokiej niż ośrodkami gospodarczymi, które ostro konkurowały z miejscowościami o wyższej randze politycznej. Chicago, Moskwa i Osaka szczególnie dobrze ucieleśniały ten typ. Zalety miasta, które rzeczywiście się liczyły, były teraz inne: lepsza organizacja społecznego podziału pracy, lepsze udostępnienie kompleksowych usług (choćby w sektorze finansowym, bardziej złożone mechanizmy działania rynku, szybsza komunikacja. Dzięki nowym technologiom (żegluga parowa, budowa kanałów, kolej żelazna, telegraf itd.) duże miasta mogły ogromnie rozszerzać zasięg swojego działania [...]. Zarówno w kontekstach niekolonialnych, jak i kolonialnych to miasta portowe notowały szczególnie duże przyrosty"1. s. 345 .

${ }^{1}$ J. Osterhammel, Historia XIX wieku. Przeobrażenie świata, przekł. J. Kałążny, Poznań 2013, 
Celem artykułu jest przedstawienie procesów, które w XIX w. ukształtowały Szczecin jako miasto nowoczesne, a które znalazły swój opis w pracy Martina Wehrmanna Geschichte der Stadt Stettin. Zagadnienie to jest dość słabo rozpoznane przez badaczy, co zresztą odnosi się w ogóle do omawianego dzieła, które - mimo swego znaczenia - nie stało się dotąd obiektem gruntowniejszych badań. Nieco więcej informacji można znaleźć na temat samego historyka i autora Geschichte der Stadt Stettin. Pomijając krótkie słownikowe hasła i popularne teksty wspomnieniowe, które ukazały się w niemieckiej prasie regionalnej ${ }^{2}$, powstało kilka artykułów dotyczących postaci Martina Wehrmanna. Do najważniejszych z nich należą artykuły Remberta Untersella pt. Martin Wehrmann (1861-1937) als Historiograph Pommerns. Ein Porträt oraz Dirka Melliesa pt. Martin Wehrmann, der Geschichtsschreiber Pommerns. Z polskojęzycznych tekstów należy wymienić artykuł Macieja Szukały pt. Martin Wehrmann i Otto Kunkel - ich rola w nauce i kulturze Szczecina końca XIX i pierwszej połowy XX wieku, który ukazał się w zbiorowym opracowaniu pt. Muzealnicy, archiwiśsi i bibliotekarze szczecińscy w XX wieku pod redakcją Kazimierza Kozłowskiego ${ }^{3}$. Żadna z prac poświęconych Wehrmannowi nie skupiła się jednak na zsubiektywizowanym obrazie dziewiętnastowiecznego Szczecina, który przestawia autor Geschichte der Stadt Stettin.

$\mathrm{Na}$ potrzeby artykułu skorzystałam $\mathrm{z}$ definicji miasta nowoczesnego, zaproponowanej przez Krzysztofa K. Pawłowskiego, którą rozszerzyłam o cechy wskazane przez Marię Nietykszę oraz Bohdana Jałowieckiego. Najpopularniejszą definicją miasta nowoczesnego, funkcjonującą $\mathrm{w}$ wielu pracach naukowych, jest właśnie ta zaproponowana przez Pawłowskiego w artykule pt. Narodziny miasta nowoczesnego: „Pod pojęciem miasta nowoczesnego możemy rozumieć taki organizm urbanistyczny, który wykorzystując do maksimum zdobycze cywilizacyjne mógł zapewnić optymalne

${ }^{2}$ Zob. Hasło Wehrmann Martin, [w:] Deutsches Literatur - Lexicon, t. 29, Berlin i in. 2009, s. 206-207; G. Grewolls, Wehrmann Martin, [w:] Wer war wer in Mecklemburg und Vorpommern: das Personenlexicon, Rostock 2011; P. Bode, Martin Wehrmann, der Geschichtsschreiber Pommerns, „Burschenschaftliche Blätter” 1962, r. 77, z. 1, s. 24; W. Dahle, Martin Wehrmann zum 70. Todestag, "Stettiner Bürgerbrief” 2007, s. 29-31; tegoż, Einer des Groß en seines Fachs. Vor 70. Jahren starb der pommersche Historiker Martin Wehrmann, "Heimatkurier. Regionalbeilage des Nordkurier, der Schweriner Volkszeitung und der Norddeutschen Neuesten Nachrichten" nr 45, 1 października 2007 r., s. 24; Vor 150 Jahren in Stettin geboren: Martin Wehrmann, "Die Pommersche Zeitung" 2011, t. 6, nr 24, s. 4.

${ }^{3}$ R. Untersell, Martin Wehrmann (1861-1937) als Historiograph Pommerns. Ein Porträt, „Zeitschrift für Ostmitteleuropa-Forschung" 1995, nr 44, s. 374-390; D. Mellies, Martin Wehrmann und die Geschichtsschreibung in Pommern, [w:] Die Demminer Kolloquien zur Geschichte Vorpommerns, red. H. Rischer, D. Schleiner, Greiswald 2012, s. 213-222; M. Szukała, Martin Wehrmann i Otto Kunkel - ich rola w nauce i kulturze Szczecina końca XIX i pierwszej połowy XX wieku, [w:] Muzealnicy, archiwiści i bibliotekarze szczecińscy w XX wieku, red. K. Kozłowski, Szczecin 2002. 
warunki bytu i rozwoju kulturalnego swych mieszkańców"4 ${ }^{\prime \prime}$ Ogólną definicję Pawłowski rozwija w swoim artykule, konkretyzując ją na przykładzie Lwowa. Wyznacznikiem lwowskiej nowoczesności miał być rozwój przestrzenny miasta, jego infrastruktura (oświetlenie, tramwaje, kanalizacja) zaadoptowanie zieleni, rozwój szkolnictwa, budownictwo reprezentacyjnych gmachów, szpitali i obiektów sakralnych oraz zabudowa willowa. Chociaż autor artykułu przytacza również przykład Szczecina (a mianowicie zwraca uwagę na charakterystyczny układ przestrzenny, dzięki któremu miasto to „wybijało się spośród wielu innych realizacji urbanistycznych ostatnich dziesiątków XIX stulecia"5), należy zauważyć, że wymienione przez niego cechy obejmują tylko część zmian zachodzących w nowoczesnych miastach. $\mathrm{Na}$ inny aspekt miejskiej nowoczesności wskazuje Maria Nietyksza w artykule Urbanizacja - jej źródła oraz miejsce w rozwoju cywilizacji europejskiej, w którym podkreśla rolę administracji państwowej przy rozwoju miast. Nietyksza zaznacza, że w XIX w. nowego znaczenia nabrały funkcje administracyjne, co w głównej mierze wiązało się z rozwojem struktur administracji państwowej i co - później - powodowało zmiany w hierarchii miast, tzn. zróżnicowania ich roli w sieci miejskiej: „Miasta, które pełniły funkcje administracyjne, a więc oddziaływały na określone terytorium kraju, przyciągały też inicjatywy oświatowe, kulturalne, dobroczynne itp. osób prywatnych, stowarzyszeń, fundacji"6. Uwaga Nietykszy jest nad wyraz celna w przypadku Szczecina, który pełnił ważne funkcje administracyjne. Za najsilniej oddziaływający czynnik miastotwórczy Nietyksza uważa przemysł i rozwój sieci kolei żelaznych oraz umożliwienie przewozu ładunków na duże odległości, które miały kluczowe znaczenie dla nowoczesnej gospodarki. Wśród istotnych aspektów zwraca także uwagę na przewrót w systemie komunikacji, który dotyczył nie tylko przewozu osób i towarów, ale także usprawnił formy przekazu i upowszechniania informacji, co było znaczące nie tylko dla gospodarki, lecz i dla życia politycznego, edukacji oraz kultury ${ }^{7}$.

Na jeszcze inne aspekty miasta doby przemysłowej zwraca uwagę Bohdan Jałowiecki, który - stosując używaną w socjologii teorię systemów - charakteryzuje pięć form przestrzennych, czyli obszarów o określonym przeznaczeniu i funkcji wraz z towarzyszącymi im urządzeniami i wyposażeniem materialnym. Wśród form przestrzennych wymienia obszary: produkcji, konsumpcji, władzy, symboliki i wymiany. Jałowiecki zaznacza także to, co pojawi się

${ }^{4}$ K.K. Pawłowski, Narodziny miasta nowoczesnego, [w:] Sztuka 2. połowy XIX wieku, red. T. Hrankowska, Warszawa 1973, s. 52.

${ }^{5}$ Tamże, s. 58.

${ }^{6}$ M. Nietyksza, Urbanizacja - jej źródła i miejsce w rozwoju cywilizacji europejskiej w „długim” XIX wieku (do 1914 r.), [w:] Cywilizacja europejska. Eseje i szkice z dziejów cywilizacji i dyplomacji, red. M. Koźmiński, Warszawa 2010 , s. 345-346.

7 Tamże, s. 345. 
u Wehrmanna - czyli silną pozycję przedsiębiorców przemysłowych, którzy stają się "nową grupą aktorów społecznego wytwarzania przestrzeni”. Od drugiej połowy XVIII w. przestrzeni produkcji podporządkowane są pozostałe obszary miejskie, a dowodem na to jest fabryka jako dominujący element krajobrazu. Natomiast nowym symbolem przestrzeni wymiany stają się dworce kolejowe. Jałowiecki zwraca szczególną uwagę na rolę przedsiębiorcy - który w dziewiętnastowiecznym ujęciu jest właścicielem terenu zarówno przestrzeni produkcyjnej, jak i mieszkań oraz urządzeń usługowych ${ }^{8}$. Na kartach książki Wehrmanna tak opisanych przedsiębiorców znajdziemy wielu: na czele z Johannesem Quistorpem, który dla pracowników swoich zakładów wybudował osiedle mieszkalne.

Martin Wehrmann, historyk, specjalizował się w dziejach Pomorza. Był redaktorem naczelnym miesięcznika „Monatsblätter der Gesellschaft für pommersche Geschichte und Altertumskunde", a także inicjatorem powstania stowarzyszenia naukowego zajmującego się historią Pomorza - Historische Kommission für Pommern. Do jego najważniejszych prac należą: dwutomowe Geschichte von Pommern (1919-1921), Bischof Otto von Bamberg in Pommern (1924) czy będące przedmiotem niniejszego artykułu Geschichte der Stadt Stettin (1911), w którym Wehrmann opisał kilkanaście wieków historii rodzinnego miasta. Swoje rozważania na temat rozwoju Szczecina Wehrmann rozpoczyna od czasów prehistorycznych, otwierając pierwszy rozdział pytaniem: „Kiedy powstał Szczecin?", a kończąc charakterystyką sytuacji w mieście w czasach sobie współczesnych. Choć opisywał także własne odczucia dotyczące czasów, w których żył, starał się być obiektywnym: w ostatnim rozdziale korzystał m.in. z dokumentów z magistratu z lat 1910 i 1911. Najwidoczniej autor chciał, by Geschichte der Stadt Stettin było nie tylko syntezą dziejów miasta, ale także jak najbardziej aktualnym opisem stanu Szczecina. Całą książkę wieńczy omówienie literatury oraz źródeł, z których Wehrmann korzystał - jest to spis imponujący, ponieważ historyk nie tylko zapoznał się z ogromną ilością źródeł (m.in. z kronik Tomasza Kanzowa i Jana Bugenhagena), ale także powoływał się na literaturę mu współczesną (nie tylko z zakresu historii, ale także np. geologii).

W swoim dziele poświęconym Szczecinowi Wehrmann jasno precyzuje okres, w którym nastąpiły procesy modernizacyjne. Impulsem do zmian była odbudowa miasta po okupacji francuskiej, która miała miejsce w latach 18061813. Wehrmann szczególnie źle oceniał czas, w którym w Szczecinie stacjonowała armia francuska. Autor Geschichte der Stadt Stettin nazywa ten okres „,zzasem cierpienia”, ,"smutnym czasem”, , „ciężką próbąa"9. Współcześnie hi-

${ }^{8}$ B. Jałowiecki, Miasto w dobie przemystowej. Uwagi o podejściu systemowym, [w:] Miasto i kultura polska dobry przemystowe, t. 1, Przestrzen, red. H. Imbs, Wrocław 1988, s. 40-44.

${ }^{9}$ M. Wehrmann, Geschichte der Stadt Stettin, Stettin 1911, s. 420-435. 
storycy wykazują, iż kilkuletnie stacjonowanie wojsk napoleońskich nie było dla miasta i jego mieszkańców bardzo uciążliwe, a nawet wiązało się z pewnymi korzyściami ${ }^{10}$. Zapewne trudno było Wehrmannowi pisać o niesławnej kapitulacji miasta, które zostało zajęte przez nieliczny (około sześciuset żołnierzy) oddział kawalerii pod dowództwem generała Lasalle'a (dla porównania: w tym czasie szczeciński garnizon liczył ok. dziesięć tys. żołnierzy). Francuzi opuścili miasto w grudniu 1813 r., kiedy Napoleon uznał, że nie ma możliwości utrzymania w głębi Prus jakichkolwiek francuskich enklaw. Wehrmann podsumowywał "ten smutny czas" słowami, że stanowił on jednak chwalebną epokę w historii miasta oraz „działał oczyszczająco na przytomność Szczecinian i obudził w nich nowy zapał i nowe poczucie własnej wartości"11.

Pierwszym krokiem władz miejskich była odbudowa zniszczonych dzielnic. Wehrmann skrupulatnie wylicza osoby i instytucje, które przyczyniły się do odnowy przestrzeni miejskiej. Pomoc finansowa płynęła zarówno ze strony rady miejskiej (która w dużej mierze przeznaczyła pieniądze na rzecz mieszkańców Dąbia oraz Zdrojów), jak i od instytucji spoza terenu kraju: na odbudowę przedmieść Londyński Komitet Pomocy podarował Szczecinowi tysiąc funtów sterlingów. W 1819 r. rozpoczął działalność Instytut Pomocy Obywateli. Wdowy i sieroty wspierane były przez stowarzyszenia kobie$\mathrm{ce}^{12}$. Wehrmann zwraca uwagę na fakt, że pomimo trudnej sytuacji miasta po okupacji, szczecinianie myśleli także o swojej ojczyźnie: radny Masche, który uzbierał 1025 talarów na założenie pomorskiego Pułku Kawalerii, w kwietniu 1815 r. zorganizował zbiórkę pieniędzy, z której dochód (718 talarów) przeznaczył na wyposażenie dla ochotników. Wehrmann zaznacza, że mieszkańcy brali czynny udział w wydarzeniach z 1814 i 1815 r., a szczególnym wydarzeniem - wedle jego relacji - było przybycie w grudniu 1815 r. do Szczecina 1. Pomorskiego Pułku Piechoty, którym dowodził książę Fryderyk Wilhelm ${ }^{13}$.

Wehrmann wielokrotnie na kartach swojej książki podkreśla, że po okupacji francuskiej $\mathrm{w}$ najtragiczniejszym stanie znajdowały się przedmieścia. Ratunkiem na ich odbudowę była Komisja do spraw Odbudowy Przedmieść, która została powołana przez Johanna Augusta Sacka - nadprezydenta prowincji pomorskiej i prezydenta rejencji szczecińskiej. Jednak problem stanowił fakt, że administracja wojskowa w mieście nie pozwoliła odbudować tych obszarów, które leżały w bezpośrednim sąsiedztwie twierdzy, co było kluczowe dla starego Dolnego Wiku. Dlatego na terenie położonym pomiędzy

${ }^{10}$ R. Skrycki, Z okresu wojny i pokoju. „Francuskie” miejsca w Szczecinie z XVIII i XIX wieku, [w:] Szczecin i jego miejsca, Trzecia Konferencja Edukacyjna, Szczecin 2010, pod red. K. Rembackiej, Szczecin 2011, s. 99.

${ }^{11}$ M. Wehrmann, dz. cyt., s. 435.

12 Tamże, s. 437.

${ }^{13}$ Tamże, s. 437. 
Odrą a szosą berlińską założono Nowy Wik, na którym osadzono mieszkańców zrujnowanych przedmieść. Wehrmann zwraca uwagę na fakt, że proces odbudowy pociągnął za sobą także powstanie nowych dzielnic. Na planach Szczecina pojawił się m.in. Nowy Turzyn (Neu Turnei) - osiedle, które powstało na północ od przedmieścia Turzyn, leżącego w bezpośrednim sąsiedztwie twierdzy ${ }^{14}$. W 1823 r. prezydent Sack zakupił tereny znane pod nazwą Velthustensche Garten. Według założeń władz miejskich na tym terenie miała odbywać się hodowla królików oraz uprawa warzyw: Sack chciał w ten sposób dać impuls dla zakładania ogrodów i sadów. Nazwa, której używał Wehrmann w swojej pracy, nawiązywała do nazwiska właściciela tego terenu, kupca Georga Christiana Velthusena. Dziś w literaturze przedmiotu najczęściej obszar ten opisany jest jako „Ogrody Sacka”15. Na południe od ogrodów rozciągał się park Cap Cheri oraz punkt widokowy Kosakenberg (obecnie Wzgórze Hetmańskie). Tereny te wraz z pobliską wsią zostały przyłączone do miasta w 1864 r. jako Pommerensdorfer Anlage (Pomorzany) $)^{16}$.

Istotną z punktu widzenia Wehrmanna była także zapomniana już dziś przez mieszkańców osada Grünhof (obecnie: Bolinko), słynąca na początku XIX w. m.in. z Długich Ogrodów i Miedzianego Młyna. Wehrmann wskazuje, że w osadzie znajdował się także Dworek Księżniczki Elżbiety - autor książki sporo miejsca poświęca dziejom tego miejsca. Nie należy jednak temu się dziwić - Elżbieta Krystyna Brunszwicka, pierwsza małżonka Fryderyka Wilhelma II, była osobą powszechnie lubianą przez mieszkańców miasta i funkcjonowała w ich świadomości jeszcze długo po swojej śmierci w 1840 r. ${ }^{17}$ Interesujący jest fakt, że autor pominął nazwę samego dworku, którą nadała mu Elżbieta:Friedrichsgnade, czyli „Łaska Fryderyka” - księżna uzyskała zgodę na zakupienie dworku już po śmierci swojego byłego męża i wstąpieniu na tron jego syna, Fryderyka Wilhelma III $^{18}$. Wieś Grünhof została przyłączona do miasta w 1859 r. ${ }^{19}$ Natomiast w 1855 r. połączono pobliskie wsie Grabow (Grabowo) i Bredow (Drzetowo) oraz nadano im prawa miejskie ${ }^{20}$. Tereny te włączono w granice miasta w kwietniu 1900 r. Jedenaście lat później dołączono do Szczecina nowo wybudowane osiedla Braunsfelde i Neuwestend

14 Tamże, s. 439.

15 Tamże, s. 440.

16 Tamże, s. 440.

${ }^{17}$ H. Kunert, Dożywocie w szczecińskiej twierdzy, portal Sedina.pl, http://sedina.pl/ wordpress/index. php/2005/11/15/doywocie-w-szczeciskiej-twierdzy (dostęp 10 maja 2016 r.).

${ }^{18}$ Elisabeth Christine Ulrike von Braunschweig-Wolfenbüttel, [w:] Internetowa Encyklopedia Szczecina, http://pomeranica.pl/wiki/Elisabeth_Christine_Ulrike_von_Braunschweig-Wolfen büttel (dostęp 10 maja 2016 r.).

${ }^{19}$ M. Wehrmann, dz. cyt., s. 440.

${ }^{20}$ Tamże, s. 440. 
(obecna dzielnica Pogodno) oraz folwarki: Schwarzow, Eckeberg i Zabeldorf (Niebuszewo). Wehrmann precyzuje, że w roku wydania Geschichte der Stadt Stettin miasto zajmowało powierzchnię $775,68 \mathrm{ha}^{21}$.

Szybki rozwój przedmieść zauważył nie tylko Wehrmann - odnotował to także Heinrich Berghaus, który w swojej pracy zwracał uwagę na rozwój podszczecińskiej wsi Grabowo w latach osiemdziesiątych XIX w. ${ }^{22}$

Drugim elementem miejskiej infrastruktury, który według Wehrmanna wymagał jak najszybszej renowacji, były szczecińskie tereny zielone. Zagadnieniem tym zajęło się utworzone przez mieszkańców Gesellschaft für die öffentlichen Spaziergänge (Towarzystwo Zakładania Publicznych Alei Spacerowych), które w 1814 r. przekształcono w Anlagen- und Verschönerungsverein (Związek do Spraw Parków i Upiększania Miasta) ${ }^{23}$.

Wehrmann zaznacza, że najwięcej pracy kosztowała władze miejskie naprawa miejskiego budżetu. Aby podkreślić, jak fatalne w tym zakresie było położenie miasta, autor Geschichte der Stadt Stettin szczegółowo przytacza miejskie sprawozdanie finansowe z 1814 r., w którym wpływy wynosiły zaledwie 37701 talarów, podczas gdy wydatki - aż 130933 talarów. Dodatkowo dochodziło do tego zadłużenie miasta, które wynosiło pięćset tys. talarów i odsetki od tego: prawie dziesięć tys. talarów rocznie ${ }^{24}$. Ponieważ władze miejskie działały opieszale, w $1816 \mathrm{r}$. zaingerowały w tej sprawie władze rejencji. Przeprowadzono kontrolę $e^{25}$, która w sprawozdaniu końcowym zarzuciła miejskim urzędnikom "upór oraz opór" przed nowymi reformami. Wobec groźby interwencji Berlina magistrat niechętnie przystał na przeprowadzenie reformy administracyjnej. Wehrmann nie przybliża jej szczegółów: wiadomo jednak, że po pierwszych sukcesach reformatorskich zapał radnych ostygł i - choć dług miasta został zredukowany z pięciuset tys. talarów do 230 tys. talarów, to wciąż były widoczne zaniedbania urzędników. W 1829 r. doszło do kolejnego przeglądu finansów. W sprawozdaniu wykazano zaniedbania w prowadzeniu miejskiego budżetu, w tym brak sprawozdań rachunkowych. Wehrmann zaznacza, że nieporządek wśród miejskich finansów panował długo: nie pomogły mu krótkie administrowanie nadburmistrza Kirsteina ani rządy Heinricha Ferdynanda Steinicke. Kres urzędniczej opozycji położył dopiero Andreas Friedrich Masche - burmistrz Szczecina w latach 1824-1832 oraz nadburmistrz w latach 1832-1845. Był tak dalece doświadczonym urzędnikiem, że Wehrmann charakteryzuje go jako "Znawcę stanu Szczecina". Dzięki jego staraniom już w czerwcu 1834 r. zostały pod-

${ }^{21}$ Tamże, s. 498.

${ }^{22}$ H. Berghaus, Geschichte der Stadt Stettin, der Hauptstadt von Pommern, Berlin 1875.

${ }^{23}$ M. Wehrmann, dz. cyt., s. 439.

${ }^{24}$ Tamże, s. 445.

${ }^{25}$ Wehrmann podaje jedynie nazwiska radnych, którzy ją przeprowadzili: Hammann i Uve. 
jęte kroki Rejencji, których celem było wyeliminowanie licznych uchybień w Magistracie. Od 1836 r. regularnie publikowano budżetowe sprawozdania miasta.

Jako główną przyczynę poprawy miejskich wydatków Wehrmann podaje otrzymanie zapomogi od państwa. Szczecinowi przyznano sumę 10400 talarów, a następnie zwolniono miasto ze spłaty dużej części pożyczki wraz z odsetkami. Przez kilka lat Szczecin otrzymywał także regularne dotacje od państwa. Pomogła poza tym nowa ordynacja podatkowa: po wprowadzeniu ustawy w $1820 \mathrm{r}$. miasto miało otrzymywać 33 proc. podatku od przemiału mąki i 16,7 proc. ogólnych podatków od obrotu mięsem rzeźnym ${ }^{26}$.

Warto zaznaczyć, że usprawnienie miejskich finansów nie było jedyną dziedziną, przy której magistrat działał opieszale. Wehrmann przytacza także anegdotę o tym, że już w kwietniu 1810 r. rozpoczęła działalność dyrekcja policji, która podlegała magistrackiemu nadsekretarzowi - dyrektorowi Stolle. Jej funkcjonowanie jednak od początku powodowało spory z magistratem, który sprzeciwiał się ponoszeniu kosztów utrzymania trzydziestoosobowego urzędu ${ }^{27}$.

Wielokrotnie na kartach Geschichte der Stadt Stettin Wehrmann podkreślał zasługi Korporacji Kupieckiej, która powstała w listopadzie 1821 r. Warto w tym miejscu zaznaczyć, że autor Geschichte der Stadt Stettin poświęcił tej instytucji nawet osobną pracę ${ }^{28}$. Celem istnienia korporacji była ochrona interesów żeglugi oraz handlu. Na jej czele stał dziewięcioosobowy zarząd z przewodniczącym - pierwszą osobą piastującą to stanowisko był Johann Rahm. Kilkakrotnie zmieniały się podstawy prawne, według których funkcjonowała ta instytucja: pierwszy statut, który pochodził z 1821 r., w 1861 r. został zmieniony po wprowadzeniu w Prusach Kodeksu Handlowego. W całości statut został zmieniony w $1871 \mathrm{r}$.

Korporacja uchodziła za zrzeszenie elitarne. Członkowie posiadali kaufmanische Rechte, czyli prawa kupieckie: był to obowiązek poprawnego prowadzenia ksiąg, zatrudniania kwalifikowanego personelu oraz posiadania zaufania domów bankowych. Wehrmann podkreśla, że wśród członków znalazły się osoby niezwykle zasłużone dla rozwoju miasta. Siedziba zrzeszenia mieściła się początkowo w starym Domu Żeglarza przy ul. Schuhstraße. W 1836 r. zadecydowano o wybudowaniu nowej siedziby: usytuowano ją nieopodal Starego Ratusza. Plany budowli przygotował radca budowlany z Berlina Mathias, a wykonanie nadzorował Kremser - architekt miejski.

${ }^{26}$ M. Wehrmann, dz. cyt., s. 447.

${ }^{27}$ Tamże, s. 425.

${ }^{28}$ M. Wehrmann, Festdchrift zum Hundertjährigen Bestehen der Korpotation der Kaufannschaft zu Stettin, Szczecin 1921. 
W nowej siedzibie działał także klub „Abendhalle”. W 1872 r. Korporacja liczyła 728 członków ${ }^{29}$.

Wehrmann podkreśla działalność kupców na wielu płaszczyznach funkcjonowania miasta. Jedną z najważniejszych zasług Korporacji Kupieckiej była rozbudowa portu. Zdawano sobie sprawę, że obecny port jest w swojej formie przestarzały. Korporacja Kupiecka brała także udział w przebudowie nabrzeży: jej przewodniczący konsultował plan zagospodarowania tego obszaru w 1853 r. z pruskim ministrem handlu. Korporacja Kupiecka przyczyniła się także do wybudowania nowego budynku teatru, który stanął na Königsplatz. Budynek otwarto uroczyście 1 października 1849 r. i wystawiono wówczas Egmonta Johanna Wolfganga Goethego. Wehrmann zaznacza, że teatr miał nieoceniony wpływ na mieszkańców Szczecina.

Autor Geschichte der Stadt Stettin wielokrotnie podkreślał, że centralnym punktem miasta jest port i że jego prawidłowe funkcjonowanie jest niezbędne dla jego dalszego rozwoju. Szczegółowo opisuje więc wszelkie prace związane z modernizacją: w 1827 r. rozbudowano Bulwar, na którym - po wcześniejszym usunięciu budek, spichlerzy oraz innych budowli, w tym składu ${ }^{30}$, postawiono Budenhaus - budynek, który pełnił funkcje handlowe. Na obszarze zwanym Pladrin ${ }^{31}$ oraz na terenie Łasztowni Stoczniowej postawiono nowe magazyny przeznaczone na składowanie śledzi. W $1838 \mathrm{r}$. wybudowano na prawym brzegu rzeki skład towarów wraz z ogromnym spichlerzem (Packhof), a pięć lat później do portu dołączono także wybrzeże znajdujące się naprzeciwko nowo wybudowanego dworca. W 1850 r. ukończono nabrzeże dla parowców. Aby ułatwić przeładunek towarów, w latach 1864-1868 postawiono stację kolejową Port Centralny - był to plac nad Parnicą, który usytuowany był między nabrzeżem ze statkami oraz linią kolejową. W 1867 r. długość szczecińskich nabrzeży wynosiła 10700 stóp $p^{32}$.

Wehrmann zwraca również uwagę na fakt, że Korporacja Kupiecka monitorowała sytuację związaną z cłami sundzkimi ${ }^{33}$. Ich zniesienie przez Danię w 1853 r. było ważnym wydarzeniem dla rozwoju pomorskiej żeglugi ${ }^{34}$. Ponieważ ułatwiało to podróż morską do Ameryki, w tym celu powołano do życia w 1869 r. spółkę Baltische Lloyd. Armator ten istniał zaledwie przez

${ }^{29}$ M. Wehrmann, Geschichte der Stadt Stettin, s. 451.

${ }^{30}$ Wehrmannowi chodziło o tzw. Unterste Sellhaus lub Nieder-Sellhaus, który znajdował się pomiędzy ul. Rybaki a Środową. Używany był do składowania zboża, ryb oraz soli.

${ }^{31}$ Bagnisty teren w południowo-wschodniej Łasztowni.

32 M. Wehrmann, Geschichte der Stadt Stettin, s. 453.

${ }^{33}$ Chodzi o cła wprowadzone przez Danię w XV w. dla obcych statków przepływających przez cieśninę Sund.

${ }^{34}$ Przeciętne roczne opłaty w Sundzie wynosiły w pierwszej połowie XIX w. ok. czterysta tys. marek rocznie, ponadto miasto musiało też płacić $w$ cieśninie dodatkowo $z$ tytułu wynagrodzenia dla urzędników duńskich i prawa przepływu przez cieśniny. 
osiem lat - po licznych wypadkach na morzu statków tej spółki zadecydowano o jej likwidacji w $1876 \mathrm{r}^{35}$

Wehrmann podkreśla, że opisane przez niego budowle związane z wodą były istotne, ponieważ zwiększały ruch statków (na rok 1814 przypadły 1524 statki wpływające i 1128 statków wypływających; z kolei w 1874 r. liczby te kształtowały się na poziomie odpowiednio: 1924 i 1951) ${ }^{36}$.

Wśród prac związanych z budownictwem wodnym Wehrmann pisze także o zmodernizowaniu toru wodnego na Świnie oraz Cieśnicy, tak że od 1862 r. do Szczecina mogły przypływać statki z zanurzeniem do 4,8 m. Interesującym jest fakt, że historyk swoich rozważań nie ogranicza $w$ tym przypadku do Odry, ale nawiązuje także do rozwoju żeglugi w Świnoujściu: odnotował nawet fakt, że w $1857 \mathrm{r}$. postawiono tam latarnię morską ${ }^{37}$. Zdawał sobie sprawę z tego, że bez odpowiednio przystosowanego portu nad Świną rozwój portu w Szczecinie nie będzie możliwy.

Istotnym wydarzeniem dla Wehrmanna było także założenie w $1826 \mathrm{r}$. Towarzystwa Żeglugi Parowej Szczecin-Świnoujście. Wehrmann nie podaje tej nazwy, jednak rozpisuje się na temat flagowej działalności tego towarzystwa: kursów parowców. Pierwszy rejs do Świnoujścia został wykonany 8 maja 1826 r. przez parowiec „Kronprinzessin Elizabeth” i trwał sześć godzin. Bilet $\mathrm{w}$ pierwszej klasie kosztował dwa talary oraz piętnaście gr. Właściciele parowca - Lemonius oraz Rahm - wielokrotnie zapewniali, że jest to środek transportu pewny i bezpieczny ${ }^{38}$. Mimo to, rozwój żeglugi parowej pociągnął za sobą powstanie towarzystw, które zajmowały się ubezpieczaniem przewozów (w tym Towarzystwo Ubezpieczeń Pomerania) ${ }^{39}$.

W swoich rozważaniach Wehrmann zauważa, że szybko po okupacji francuskiej na nogi stanął szczeciński przemysł. Już w 1817 r. Heinrich Dohrn oraz Johann Friedrich Velthusen powołali do życia Pommersche Provinzional-Zucker-Siederei, czyli Pomorską Prowincjonalną Rafinerię Cukru ${ }^{40}$. Wehrmann zauważa, że była to o tyle istotna instytucja, iż położyła podstawy

${ }^{35}$ M. Wehrmann, dz. cyt., s. 454.

${ }^{36}$ Tamże, s. 453.

${ }^{37}$ Tamże, s. 452.

${ }^{38}$ Warto w tym miejscu zaznaczyć, że Lemonius był gorącym orędownikiem wprowadzenia parowców do żeglugi na Odrze - wiązało to się z walką o pozycję portu, którą Szczecin toczył z Hamburgiem. W 1824 r. Lemonius pisał do Berlina: „Podczas gdy do Hamburga statki docierają Łabą pod prąd do rzeki, jednostki zdążające do Szczecina stoją często tygodniami przy przeciwnym wietrze w Świnoujściu i Zatoce Przytorskiej. Gdyby można było holować wychodzące ze Świnoujścia statki do Szczecina przy pomocy parowców, wówczas korzyść dana Hamburgowi stałaby się udziałem Szczecina" (cyt. za: W. Stępiński, dz. cyt., s. 120).

${ }^{39}$ M. Wehrmann, Geschichte der Stadt Stettin, s. 455.

${ }^{40}$ Wehrmann pisze, że panowie powołali do życia to przedsiębiorstwo, jednak według Włodzimierza Stępińskiego - tylko reaktywowali cukrownię, która była nieczynna od 1811 r., por. Dzieje Szczecina, s. 146. 
pod majątki wielu szczecińskich rodzin. Kolejna rafineria cukru powstała w 1835 r., a dwanaście lat później następną założyli znani szczecińscy kupcy: Witte, Scalla, i Ludendorf. Zaczęły powstawać także zakłady związane z produkcją maszyn: w 1837 r. Szczecińska Odlewnia Żelaza, która najpierw znajdowała się w rękach rodziny Meisterów, by potem trafić do Würdena. W tym samym czasie istniała mniejsza odlewnia żelaza, należąca do Bräunlicha ${ }^{41}$. Wehrmann wspomina również o trzech znanych szczecińskich stoczniach: Oderwerke, Vulcan oraz o stoczni rodziny Nüscke. Ta pierwsza została założona przez Möllera i Holberga w 1854 r. jako przedsiębiorstwo prywatne, które niecałe dwadzieścia lat później zostało przekształcone w spółkę akcyjną. Z kolei Vulcan powstał w 1851 r. z inicjatywy Früchtenichta i Brocka. W 1859 r. zakład ten wyprodukował pierwszą lokomotywę, a w 1866 r. dostarczył pruskiej Marynarce pierwszy mały okręt wojenny. W 1870 r. Vulcan zajmowała obszar ośmiu ha i zatrudniała 1800 pracowników. Stosunkowo najmniej znaną (i najskromniej opisaną u Wehrmanna) jest stocznia Nüscke \& Co. AG, w której wyprodukowano m.in. pierwsze w Prusach parowe kanonierki ${ }^{42}$. Choć najczęściej w kontekście szczecińskich zakładów budowy okrętów przytacza się stocznię Vulcan, to należy nadmienić, że jeszcze przed jej powstaniem - dzięki takim zakładom, jak stocznia rodziny Nüscke, przedsiębiorstwo Carmesin Werft czy stocznia D. Möllera - Szczecin był znanym w Prusach ośrodkiem budowy statków ${ }^{43}$.

Kolejnych zakładów przemysłowych Wehrmann nie opisuje już tak szczegółowo. Autor Geschichte zaznacza, że tego typu instytucji w XIX w. powstało wiele i wymienia tylko te najważniejsze, w tym: młyn parowy w Żelechowej, młyn należący do Zandera, zakłady chemiczne na Pomorzanach oraz w Glinkach, fabryka wyrobów szamotowych i cementownia założona przez Francuza Friedricha Didera, cementownia w Zdrojach należąca do Gustava Toepffera oraz Heinricha Grawitza czy zakłady Stöwer ${ }^{44}$. W 1873 r. w Szczecinie istniały 143 zakłady przemysłowe, w których zatrudniono 9433 pracowników - Wehrmann zaznacza, że w czasie powstawania Geschichte der Stadt Stettin liczba osób zatrudnionych zwiększyła się do 22 tys. ${ }^{45}$

Wehrmann opisuje szczegółowo rozwój komunikacji, który nastąpił w latach 1814-1873. Sporo miejsca autor Geschichte der Stadt Stettin poświęca połączeniom drogowym oraz kolejowym, podkreślając przy tym fakt, iż ich najważniejszą cechą jest skrócenie dystansu do Berlina. W latach 18221827 wybudowano szosę łączącą Szczecin z miejscowością Gartz - trasa ta

\footnotetext{
${ }^{41}$ M. Wehrmann, Geschichte der Stadt Stettin, s. 461.

42 Tamże, s. 462.

${ }^{43}$ W. Stępiński, dz. cyt., s. 153.

${ }^{44}$ M. Wehrmann, Geschichte der Stadt Stettin, s. 462.

${ }^{45}$ Tamże, s. 511.
} 
byłą częścią drogi z Berlina do Gdańska. Budowano także arterie w kierunku Pomorza Przedniego oraz do Stargardu: to ostatnie przedsięwzięcie wiązało się z rokowaniami z mieszkańcami Dąbia, gdyż to przedmieście musiało zostać przebudowane. Natomiast w 1855 r. powstała szosa łącząca Szczecin $\mathrm{z}$ Policami ${ }^{46}$.

Za jeden z pierwszych nowoczesnych procesów Wehrmann uznał proces modernizacji szczecińskich ulic. $\mathrm{W}$ pierwszej połowie XIX w. zamiast bruku stosowano luźno rozrzucone kamienie, a rynsztoki i przybudówki ograniczały jezdnię. W latach czterdziestych w Szczecinie pojawiły się pierwsze chodniki: na Reifschlägerstraße (obecnie ul. Mściwoja II) i części nabrzeża na Łasztowni. W 1843 r. pojawiły się także przed dworcem kolejowym, jednak na dalsze prace zabrakło pieniędzy ${ }^{47}$.

Istotnym zagadnieniem dla Wehrmanna były szczecińskie mosty. W latach 1853-1854 wybudowano most, który łączył dworzec kolejowy z Kępą Parnicką (Silberwiese), a czternaście lat później wzniesiono pierwszy w mieście most obrotowy, który zlokalizowany był w pobliżu dworca kolejowego. W podobnym czasie wzniesiono Bahnhofsbrücke (Most Dworcowy), a w 1910 r. ukończono budowę Baumbrücke (Mostu Kłodnego), przez który przebiegała linia kolejowa. W 1907 r. ukończono budowę nowego Parnitzbrücke (Most Portowy) ${ }^{48}$. Interesującą wzmiankę autor pozostawił przy informacji o przebudowie Langebrücke (Mostu Długiego), która miała miejsce w 1820 r. Wehrmann zaznaczył, iż sugerowano, aby budowli nadać imię monarchy, jednak nie udało się to ze względu na szacunek dla starej nazwy. Autor dodaje, że ów szacunek był większy niż osiemdziesiąt lat później $^{49}$ : w latach 1900-1903 most ten wyburzono i wybudowano na jego miejscu nowy, który otrzymał nazwę Hansabrücke (dzisiejszy Most Długi) ${ }^{50}$.

Za jeden z najważniejszych momentów w dziejach miasta Wehrmann uważa połączenie Szczecina linią kolejową z Berlinem. Pierwsze plotki o tym przedsięwzięciu pojawiły się już 14 sierpnia 1835 r. w „Börsen - Nachrichten der Ost-See". Z inicjatywą wyszli przedstawiciele szczecińskiego kupiectwa i 1 marca 1836 r. założono Komitet Kolei Szczecińsko-Berlińskiej. Budowa podzielona była na trzy etapy: najpierw wybudowano odcinek łączący Eberswalde z Berlinem, następnie przygotowano fragment Eberswalde-Angermünde, na samym końcu połączono Angermünde ze Szczecinem. Uroczyste otwarcie linii kolejowej nastąpiło 15 sierpnia 1843 r., a pierwszym pasażerem na nowej trasie był król Fryderyk Wilhelm IV, którego miasto przywitało ucztą.

\footnotetext{
46 Tamże, s. 455.

47 Tamże, s. 458.

48 Tamże, s. 501.

49 Tamże, s. 453.

50 Tamże, s. 501.
} 
Wehrmann opisuje emocje, jakie wiązały się z nowym środkiem transportu: „Wiele nadziei, życzeń i oczekiwań wiązało się z tą trasą, która, jak było mówione: jest nową obrączką $\mathrm{w}$ tym łańcuszku, który wkrótce powinien połączyć wspólnie narody Europy w stałym pokoju i rosnącym dobrobycie" ${ }^{51}$. Takie powiedzenie łączyło się z faktem, że w dużej mierze za powstaniem kolei berlińsko-szczecińskiej stała Korporacja Kupiecka, która widziała w nowym środku transportu szansę na rozwój handlu. W pierwszym rozkładzie jazdy połączenia na trasie Szczecin-Berlin odbywały się dwa razy w ciągu dnia: na trasie znajdowało się sześć stacji, a sam przejazd trwał 4,5 godziny. Podobnie jak w przypadku parowców, tak i przy kolei zapewniano, że podróż taka nie wiąże się z żadnym niebezpieczeństwem. W 1851 r. wprowadzono nawet jedno połączenie nocne pomiędzy stolicą Prus a stolicą prowin$\mathrm{cji}^{52}$.

Wehrmann zaznacza, że połączenie Szczecin-Berlin otworzyło drogę dla dalszego rozwoju kolei na Pomorzu i zwraca uwagę, że w początkowym okresie istnienia kolei Szczecin zyskał połączenia w najważniejszych kierunkach. W 1846 r. wybudowano tory ze Szczecina do Stargardu, a dwa lata później pociągnięto tę trasę dalej: do Poznania. Wkrótce także połączono stolicę prowincji z Koszalinem, a w 1863 r. - z Meklemburgią. W drugiej połowie XIX w. pociągnięto linię kolejową do Polic (którą w 1910 r. przedłużono do Trzebieży) $)^{53}$. Połączenie kolejowe zyskało także Świnoujście: od 1876 r. pociągi kursowały do osady Ducherow, położonej nad Zalewem Szczecińskim. W 1882 r. połączono Dąbie z Goleniowem, a dziesięć lat później trasę tę przedłużono do Wolina. Ważnym momentem dla rozwoju Szczecina było wybudowanie w 1877 r. trasy do Chojny i Kostrzyna: w ten sposób miasto zyskało także połączenie z Wrocławiem ${ }^{54}$.

Rozwój Szczecina związany był także z działalnością konkretnych osób, których energiczne działania przyczyniły się do jego odbudowy. Do najważniejszych obywateli miasta Wehrmann zaliczył wspomnianego już w artykule Johanna Augusta Sacka. Zanim przybył do Szczecina, Sack miał już na swoim koncie karierę polityczną w Berlinie: w 1798 r. został mianowany tajnym nadradcą finansowym w berlińskiej Generalnej Dyrekcji, a osiem lat później objął stanowisko cywilnego gubernatora Berlina. Był zwolennikiem reform Steina. W latach 1816-1831 pełnił funkcję nadprezydenta prowincji pomorskiej, a w latach 1828-1831 - prezydenta rejencji szczecińskiej. Podczas swojej prezydentury przeprowadzono wiele reform administracyjnych i samorządowych. Sack popierał rozwój handlu i przemysłu: to on był inicjatorem odby-

\footnotetext{
51 Tamże, s. 456.

52 Tamże, s. 456.

53 Tamże, s. 456.

54 Tamże, s. 503.
} 
wającej się w latach 1818-1823 rozbudowy portu w Świnoujściu, a także przyczynił się do obniżki ceł na importowane towary spoza Morza Bałtyckiego. Po okupacji napoleońskiej - z pomocą szczecińskich kupców - zorganizował na Łasztowni targ wełny. Wehrmann zwraca poza tym uwagę na fakt, że taka działalność pociągała za sobą rozwój hoteli oraz restauracji, które cieszyły się dużą popularnością w czasie trwania targów. Nadprezydent stał za utworzeniem w Szczecinie archiwum prowincjonalnego oraz za powstaniem Pomorskiego Towarzystwa Historyczno-Archeologicznego. Był także twórcą Szkoły Żeglarskiej na Łasztowni, którą otwarto w 1823 r. Sack już w 1821 r. uzyskał tytuł honorowego obywatela Szczecina - w tym samym roku otrzymał tytuł doktora honoris causa na uniwersytecie w Halle ${ }^{55}$.

Wehrmann zwraca również uwagę na fakt, że rozwój miasta nie byłby możliwy bez wsparcia władz państwowych: szczególnie ministra Roberta von Puttkamera oraz ministra Helmutha von Maltzahn-Gultz, którzy zawsze pamiętali o interesach miasta i którzy - po zakończeniu kariery w Berlinie objęli funkcję nadprezydenta pomorskiej prowincji ${ }^{6}$.

Jednocześnie Wehrmann docenia opiekę państwa, pisząc, że była ona znacząca zarówno dla wewnętrznego, jak i zewnętrznego rozwoju miasta. Przede wszystkim jednak $\mathrm{w}$ tym zakresie podkreśla rolę monarchy, którego w mieście zawsze witano z wielką radością. Król Fryderyk Wilhelm III bywał gościem u pani Tielebein, jego syn zaś, następca tronu, co roku pojawiał się w mieście jako „Namiestnik Pomorza, dowódca Drugiego Pułku Grenadierów czy jako dowódca Pomorskiego Korpusu Armijnego" - Wehrmann podkreśla, że takie wizyty wpływały nie tylko na militarne aspekty funkcjonowania miasta, ale także jego całościowy rozwój ${ }^{57}$. Często Wehrmann zauważa, że to właśnie decyzje konkretnego króla przyczyniły się do rozwoju miasta. Dzięki zgodzie Fryderyka Wilhelma IV utworzono dzielnicę Neustadt, która została wybudowana pomiędzy dworcem kolejowym a Fortem Prusy ${ }^{58}$. To także Fryderyka Wilhelm IV w 1856 r. powołał cywilno-wojskową Komisję do Spraw Rozwoju Miasta, która miała zaradzić problemom Szczecina spowodowanym brakiem przestrzeni. $W$ obradach dotyczących problemów miejskich wzięli udział m.in. nadprezydent Ernst Senfft von Pilsach oraz nadburmistrz Hermann Hering. Jednak najskuteczniejszym lekarstwem na brak przestrzeni okazało się dopiero zniesienie szczecińskiej twierdzy ${ }^{59}$.

Istotnym procesem zachodzącym $\mathrm{w}$ dziewiętnastowiecznym Szczecinie choć Wehrmann w Geschichte der Stadt Stettin traktuje ten temat dość pobież-

\footnotetext{
55 Tamże, s. 438-468.

56 Tamże, s. 511.

57 Tamże, s. 467.

58 Tamże, s. 444.

59 Tamże, s. 444.
} 
nie - były przemiany związane z samorządem miejskim, który w ciągu XIX w. reformowano trzykrotnie. Pierwszy raz podczas okupacji francuskiej w listopadzie 1808 r., następnie - w marcu 1831 r. i ostatni raz - w 1853 r. Wehrmann skupia się na tej ostatniej zmianie, która wynikała z ordynacji miejskiej dla sześciu wschodnich prowincji monarchii pruskiej z 30 maja 1853 r. i zaznacza, że ustawa ta w zasadzie obowiązuje do czasów mu współczesnych. Utrwaliła ustrój miasta (określany jako magistracki) i dzieliła mieszkańców na trzy kategorie, przydział do których uzależniony był od od wysokości udziału w podatkach bezpośrednich ${ }^{60}$.

Wspomniano już wcześniej, że dzięki działalności Korporacji Kupieckiej w mieście powstał teatr. Ale Wehrmann w swojej pracy nie skupiał się wyłącznie na miejskim życiu teatralnym: zwrócił uwagę na szereg mniejszych wydarzeń, które przyczyniły się do rozwoju kulturalnego Szczecina. Według Wehrmanna, pierwsza połowa XIX w. była szczególna, a o jej wartości miał przesądzać fakt, że wzrosło zainteresowanie szczecinian sztuką. Wehrmann twierdzi także, że jest to czas, kiedy wiele gałęzi sztuki doczekało się należytej opieki ${ }^{61}$.

Również muzyka cieszyła się dużym zainteresowaniem Wehrmanna w Geschichte der Stadt Stettin. Przede wszystkim autor doceniał na tym polu działalność Carla Loewego, który przybył do Szczecina w 1820 r. Żaden inny muzyk czy kompozytor - według Wehrmanna - nie wpłynął tak znacząco na życie muzyczne Szczecina. Wśród jego zasług wymienia wykonanie uwertury do Snu nocy letniej Szekspira czy wykonanie Pasji św. Mateusza Bacha. Loewe przyjaźnił się z Fryderykiem Wilhelmem IV oraz prowadził w Szczecinie własną szkołę muzyczną. Wehrmann zauważa, że szczecinianie byli mu bardzo wdzięczni za wkład w życie kulturalne miasta ${ }^{62}$.

Wehrmann zaznacza, że XIX w. bardziej niż wcześniej skupiono się na opiece nad malarstwem. Wśród szczecińskich malarzy tego okresu wymienia takie osoby, jak Immanuel Heinrich Lengerich czy Ludwig Most - jak zaznacza Wehrmann, obrazy tego ostatniego wciąż były popularne w momencie wydawania Geschichte der Stadt Stettin. W listopadzie 1834 r. powołano Pomorskie Stowarzyszenie Sztuki, a w kwietniu następnego roku po raz pierwszy w Szczecinie zorganizowano wystawę sztuki i rzemiosła. Wśród wielu prezentowanych na niej prac znalazły się także te autorstwa Mosta. Ponieważ wystawa okazała się wielkim sukcesem i sprzedano wiele obrazów, zadecydowano o cyklicznym organizowaniu takich imprez ${ }^{63}$.

\footnotetext{
60 Tamże, s. 445.

61 Tamże, s. 491.

62 Tamże, s. 490.

63 Tamże, s. 491.
} 
Za istotną Wehrmann uważa także działalność różnego rodzaju stowarzyszeń naukowych. Oprócz wspomnianego wcześniej Pomorskiego Towarzystwa Historyczno-Archeologicznego wymienia stowarzyszenia skupiające fizyków oraz Stowarzyszenie Politechniczne. Inną formą rozwoju intelektualnego szczecinian były nieformalne spotkania, podczas których prowadzono kulturalne dyskusje: takim miejscem spotkań był m.in. salon pani Sophie Auguste Tilebein.

Momentem, który miał decydujący wpływ na przyszłość Szczecina i który Wehrmann nazywa najważniejszym wydarzeniem w nowej historii miasta - było zniesienie twierdzy w 1873 r. ${ }^{64}$ Autor Geschichte der Stadt Stettin wielokrotnie podkreślał, że dla dalszego rozwoju miasta pozbycie się miejskich umocnień było koniecznością ${ }^{65}$. Forteczna przyszłość już od 1856 r. była przedmiotem poważnych dyskusji Komisji do spraw Rozwoju Miasta. Nadradca regencji szczecińskiej Oskar Wehrmann ${ }^{66}$ przygotował w 1865 r. projekt, w którym podkreślał korzyści płynące dla Prus, jeśli zdecydują się sprzedać tereny twierdzy miastu. Plan ten został odrzucony przez magistrat. Najpoważniejszą przeszkodę stanowiły finanse: miasto nie potrafiło ustalić z władzami państwowymi, ile powinna wynosić kwota, za którą mogłoby wykupić tereny forteczne. Impas trwał do 1873 r. 30 maja cesarz Wilhelm I oraz Bismarck podpisali ustawę, która dotyczyła środków finansowych na przekształcenie systemu twierdz Rzeszy ${ }^{67}$. Decyzja ta $w$ dniu jej publikacji, czyli 6 czerwca 1873 r., wywołała radość szczecinian ${ }^{68}$. Zniesienie umocnień pociągnęło za sobą powstanie nowych dzielnic, choć Wehrmann zaznacza, że proces ten był niezwykle długi i żmudny, mieszkańcy wielokrotnie skarżyli się na przeciągające się prace budowlane, a sam Szczecin przez wiele lat wyglądał, według Wehrmanna, jak miasto „niedokończone” ${ }^{69}$.

Odbudowa Szczecina po francuskiej okupacji stała się bezpośrednią przyczyną zmian, które zaszły w mieście w latach 1813-1873. Wehrmann kilkakrotnie podkreśla $\mathrm{w}$ swojej pracy, że te sześćdziesiąt lat okazało się decydujące dla rozwoju miasta. Po 1813 r. miasto zmienia swój układ urbanistyczny - jego zwieńczeniem będzie oswobodzenie Szczecina z okowów twierdzy (sam Wehrmann określa mury twierdzy mianem „kajdanków”). Istotną rolę w rozwoju miasta odegrała Korporacja Kupiecka, która stała za rozwojem szczecińskiej żeglugi oraz kolei, a jej członkowie zakładali również

64 Tamże, s. 436.

65 Tamże, s. 443.

${ }^{66}$ Zbieżność nazwisk przypadkowa.

${ }^{67}$ Artykuł ósmy tej ustawy precyzuje, które twierdze zostały przeznaczone do likwidacji. Wymienione są: Szczecin, Minden, Erfurt, Wittenbergia, Casel, Grudziądz, Straslund i Kołobrzeg (B. Kozińska, dz. cyt., s. 146).

${ }_{68}^{6}$ M. Wehrmann, Geschichte der Stadt Stettin., s. 496.

${ }^{69}$ Tamże, s. 497. 
zakłady przemysłowe. Rezultaty tych wszystkich procesów składały się na szczecińską nowoczesność. Choć niektóre z jej elementów pojawiają się u autora Geschichte der Stadt Stettin jeszcze przed zniesieniem fortyfikacji („, nowoczesnym wyposażeniem miasta" historyk nazywa m.in. gazownię), to jednak najwięcej wyznaczników można zaobserwować w historii miasta po $1873 \mathrm{r}$. Istotne są wówczas nie tyle procesy, które doprowadziły do nowoczesności, ale już jej konkretne cechy.

Choć czytając opis dziewiętnastowiecznego miasta zaprezentowany przez Wehrmanna może dziwić jego podejście do niektórych zagadnień - czasami zbyt szczegółowe, innym razem zbyt ogólne - nie da się zaprzeczyć, że obraz ten jest niezwykle subiektywny. Autor Geschichte der Stadt Stettin stara się pokazać swoje rodzinne miasto (i jego mieszkańców) z jak najlepszej strony. Szczecin Wehrmanna jest miastem prężnie rozwijającym się, z nowoczesnym portem, dobrze stojącym handlem i przemysłem - $w$ tym zakładami znanymi w całych Niemczech - a także z solidnie rozwiniętym zapleczem kulturalnym oraz rekreacyjnym. Wehrmann zresztą nie krył się z tym w swoim dziele, że jego życzeniem było, by Szczecin należał do czołówki rozkwitających niemieckich miast ${ }^{70}$. Po przeczytaniu Geschichte der Stadt Stettin czytelnik może odnieść wrażenie, że miasto to jest już bardzo blisko osiągnięcia tego celu.

\section{Bibliografia}

\section{Źródła drukowane}

Wehrmann M., Geschichte der Stadt Stettin, Stettin 1911.

\section{Opracowania}

Bode P., Martin Wehrmann, der Geschichtsschreiber Pommerns, „Burschenschaftliche Blätter" 1962, r. 77, z. 1.

Dahle W., Martin Wehrmann zum 70. Todestag, „Stettiner Bürgerbrief” 2007, s. 29-31.

Elisabeth Christine Ulrike von Braunschweig-Wolfenbüttel, [w:] Internetowa Encyklopedia Szczecina, http:// pomeranica.pl/wiki/Elisabeth_Christine_Ulrike_von_Braunschweig-Wolfenbüttel (dostęp 10 maja 2016 r.).

Grewolls G., Wehrmann Martin, [w:] Wer war wer in Mecklemburg und Vorpommern: das Personenlexicon, Rostock 2011.

Kunert H., Dożywocie w szczecińskiej twierdzy, portal Sedina.pl, http:/ / sedina.pl/wordpress/index. php/2005/11/15/doywocie-w-szczeciskiej-twierdzy (dostęp 10 maja 2016 r.).

Mellies D., Martin Wehrmann und die Geschichtsschreibung in Pommern, [w:] Die Demminer Kolloquien zur Geschichte Vorpommerns, red. H. Rischer, D. Schleiner, Greiswald 2012.

Nietyksza M., Urbanizacja - jej źródła i miejsce w rozwoju cywilizacji europejskiej w „dtugim” XIX wieku (do 1914 r.), [w:] Cywilizacja europejska. Eseje i szkice z dziejów cywilizacji i dyplomacji, red. M. Koźmiński, Warszawa 2010.

Osterhammel J., Historia XIX wieku. Przeobrażenie świata, przekł. J. Kałążny, Poznań 2013.

70 Tamże, s. 519. 
Pawłowski K., Narodziny miasta nowoczesnego, [w:] Sztuka 2. połowy XIX wieku, red. T. Hrankowska, Warszawa 1973.

Skrycki R., Zokresu wojny i pokoju. „Francuskie” miejscaw Szczecinie z XVIII i XIX wieku, [w:] Szczecin i jego miejsca, Trzecia Konferencja Edukacyjna, Szczecin 2010, pod red. K. Rembackiej, Szczecin 2011.

Szukała M., Martin Wehrmann i Otto Kunkel - ich rola w nauce i kulturze Szczecina końca XIX i pierwszej połowy XX wieku, [w:] Muzealnicy, archiwiści i bibliotekarze szczecińscy w XX wieku, red. K. Kozłowski, wyd. Pedagogium, Szczecin 2002.

Untersell R., Martin Wehrmann (1861-1937) als Historiograph Pommerns. Ein Porträt, "Zeitschrift für Ostmitteleuropa-Forschung“ 1995, nr 44.

Wehrmann M., Festdchrift zum Hundertjährigen Bestehen der Korpotation der Kaufannschaft zu Stettin, Szczecin 1921.

Wehrmann Martin, [w:] Deutsches Literatur - Lexicon, t. 29, Berlin i in., 2009.

Agata Łysakowska

\title{
Rozwój dziewiętnastowiecznego Szczecina w Geschichte der Stadt Stettin Martina Wehrmanna
}

\begin{abstract}
Streszczenie
Martin Wehrmann uważany jest za przedstawiciela najważniejszych historyków zajmujących się dziejami Pomorza Zachodniego. Był członkiem towarzystw regionalnych, w tym Towarzystwa Historii i Starożytności Pomorza oraz Pomorskiej Komisji Historycznej. Pozostawił po sobie wiele prac, w tym dwutomowe Geschichte von Pommern i Geschichte der Stadt Stettin. W drugim z wymienionych dzieł Wehrmann w trzech rozdziałach (Stettins Franzosenzeit, Stettin im 19. Jahrhundert bis zur Aufgebung der Festung, Die neueste Zeit seit 1873) opisał rozwój Szczecina w XIX w. Jest to charakterystyka o tyle interesująca, iż autor pisze o mieście sobie współczesnym, zwracając uwagę na procesy, które ukształtowały Szczecin jako miasto nowoczesne, takie jak: odbudowa miasta po okupacji francuskiej, działalność Korporacji Kupieckiej, funkcjonowanie portu i żeglugi, rozwój przemysłu i komunikacji, modernizację ulic, działalność i aktywność kulturalną konkretnych osób czy wreszcie: zniesienie twierdzy. W artykule wykorzystano definicje miasta nowoczesnego zaproponowane przez Krzysztofa K. Pawłowskiego, Marię Nietykszę oraz Bohdana Jałowieckiego.
\end{abstract}

Słowa klucze: Szczecin, nowoczesność, XIX wiek, urbanizacja, miasto, przemysł, handel, architektura, infrastruktura, dziewiętnastowieczne społeczeństwo

\section{The development of $19^{\text {th }}$-century Szczecin in Geschichte der Stadt Stettin by Martin Wehrmann}

\begin{abstract}
Martin Wehrmann is considered one of the most prominent experts on the history of Western Pomerania. He was a member of various regional societies, including the Society of Pomeranian History and Antiquity, and the Pomeranian Historic Committee. He is the author of many works, including the two-volume Geschichte von Pommern and Geschichte der Stadt Stettin. In three
\end{abstract}


chapters of the latter work (Stettins Franzosenzeit, Stettin im 19. Jahrhundert bis zur Aufgebung der Festung, Die neueste Zeit seit 1873), Wehrmann described the development of Szczecin in the 19 century. This description is quite exceptional, as the author writes about the city as it was at the moment of writing, pointing to the processes which shaped Szczecin and made it a modern town, such as the reconstruction of the city following the French occupation, the activity of the Trade Corporation, the functioning of the port and maritime transport, the development of industry and transport, modernization of streets, the activity of specific people, including cultural activity, and the disassembly of the fortifications. The article used a definition of a modern town by Krzysztof K. Pawłowski, Maria Nietyksza, and Bohdan Jałowiecki.

Key words: Szczecin, modernity, $19^{\text {th }}$ century, urbanization, city, industry, trade, architecture, infrastructure, $19^{\text {th }}$-century society 